\title{
Effect of non-protected sunflower oil supplementation on milk fatty acid profile and oxidative status in Simmental cows
}

\author{
TEREZIJA SILVIJA MARENJAK'1, IVANČICA DELAŠ², NINA POLJICAK-MILAS ${ }^{1}$ and \\ JASNA PIRŠLJIN ${ }^{3}$
}

\begin{abstract}
'Department of Pathophysiology, Faculty of Veterinary Medicine, University of Zagreb, Croatia, ${ }^{2}$ Department of Chemistry and Biochemistry, School of Medicine, University of Zagreb, Croatia, ${ }^{3}$ Department of Physiology and Radiobiology, Faculty of Veterinary Medicine, University of Zagreb, Croatia
\end{abstract}

\section{Abstract}

Milk production, milk composition, milk fatty acid profiles, and antioxidant status of Simmental cows supplemented with non-protected sunflower oil were studied. Ten Simmental cows in mid-lactation were appointed for change over feeding trial with one of the diet applied: the control (WSO) diet consisted of $26 \%$ corn silage, $33 \%$ perennial ryegrass haylage, and $41 \%$ concentrate in dry matter (DM), and the experimental diet (SO) consisted of control diet supplemented with $2 \%$ of unrefined sunflower oil per cow and day. The cows were kept in indoor housing system with feeding and milking system two times daily and ad libitum water supply. The milk production and standard milk components remained unchanged during the study. The partial modification of fatty acid composition was remarked with the significantly higher linoleic and conjugated linoleic acid (CLA) (cis-9, trans-11 C18:2) concentration and significantly lower palmitic acid during the SO treatment. The blood gluthathion peroxidase (GPX) activity significantly increased and the thiobarbituric acid reactive substances (TBARS) concentration decreased significantly in the SO treatment.

The non-protected sunflower has a perceptible effect on the milk fatty acid composition in Simmental cows of our research. The lower index of lipid peroxidation and higher GPx activity in blood of cows during the SO treatment could be a consequence of the antioxidant components that are normally present in the unrefined vegetable oils. The enzyme activity reflects appropriate functioning of the antioxidant defence of cows that emphasise importance of well balanced diet during the unsaturated fatty acid supplementation.

Key words: cow, nutrition, vegetable oil, fatty acids, oxidative defence, blood

\section{Zusammenfassung}

\section{Auswirkungen der Futterergänzung mit nicht pansengeschütztem Sonneblumenöl auf das Fettsäureprofil der Milch und den Oxidationsstatus bei Simmentaler Kühen}

Untersucht wurde der Einfluss des Futterzusatzes von nicht pansengeschütztem Sonnenblumenöl auf die Milchleistung, das Fettsäureprofil der Milch und den Antioxidanzstatus bei Simmentaler Kühen. Zehn in der Mitte der Laktation stehende Kühe wurden 
ausgewählt von denen die Futterration von fünf Versuchstieren gegenüber den Kontrolltieren mit $2 \%$ nicht geschütztem Sonnenblumenöl angereichert wurde. Bei Stallhaltung erhielten die Tiere Wasser ad libitum und wurden zweimal täglich gemolken. Bei der täglichen Milchmenge sowie der Milchzusammensetzung ergaben sich während der Versuchdauer keine signifikanten Unterschiede. In der Versuchsgruppe wurde eine signifikant höhere Konzentration von C18:2 cis-9, cis-12 sowie C18:2 cis-9, trans-11 sowie eine geringere der Palmitinsäure nachgewiesen (C16:0). Bei diesen Tieren erhöhte sich auch die Glutathionperoxidaseaktivität und verringerte sich die Konzentration thiobarbitursäureaktiver Substanzen (TBARS). Der Futterzusatz ließ einen nachweisbaren Effekt auf das Fettsäurespektrum des Milchfettes der Simmentaler Kühe erkennen. Der niedrigere Index der Lipidperoxidation im Blut dieser Kühe könnte die Folge von Antioxidanzkomponenten sein, welche normalerweise in unraffiniertem Pflanzenöl vorhanden sind. Auf die Bedeutung einer ausgewogenen Diät bei einer erhöhten Zuführung von ungesättigten Fettsäuren im Futter wird hingewiesen.

Schlüsselwörter: Kuh, Ernährung, Pflanzenöl, Fettsäure, Oxidationsschutz, Blut

\section{Introduction}

The fatty acid composition of milk in Holstein Friesian cows has been extensively studied in various nutritional trials with the aim to increase the proportion of some favourable fatty acids and decrease the unfavourable fatty acids in milk (GEISSLER et al. 1994, LIEBETSEDER 1996, PRECHT and MOLKENTIN 1997, DHIMAN et al. 1999, STANTON et al. 2000, SECCHIARI et al. 2003, REGO et al. 2005). Less data are available concerning the Simmental cows' fatty acid composition under the certain feeding conditions. The Simmental cows are traditionally used for the milk and meat production in small-scale dairy farms in Croatia (MARENJAK et al. 2007). The use of unprotected vegetable oils and whole grains in the dairy cows' diet may have a limited effect on the fatty acids composition in ruminants. As a consequence of rumen biohydrogenation processes, unsaturated fatty acids from the diet are rapidly converted to saturated fatty acids by the rumen microorganisms (HARFOOT and HAZLEWOOD 1997, HOLLO et al. 2005). However, an increase in polyunsaturated fatty acids (PUFA) in the diet could possible change the pattern of rumen microbe metabolism, and consequently change the fatty acid synthesis in milk and adipose tissue of ruminants (LIEBETSEDER 1996, SZUMACER-STRABEL et al. 2001, HOLLO et al. 2005, DANNENBERGER et al. 2006). DEPETERS et al. (1995) found out also the breed specificity and difference in milk fatty acid synthesis and proportions. There are some concerns regarding the feeding PUFA to animals and possible lipid peroxidation consequences if the antioxidant elements are not sufficiently present in the organism. The defect in antioxidant defence may lead to pathogenesis of several diseases (LIEBETSEDER 1996). Diets high in PUFA may induce fibrosis and oxidative damage of the liver (BROWN et al. 2003). Recently, there are some denotations for more incidences of fat necrosis in heifers with low levels of blood GPx, Cu and vitamin E (VAN ASSELT et al. 2006). The effect of feeding regimes on lipid and on protein oxidation in dairy cows is still unknown. Therefore in order to produce high quality milk by animal diet manipulation, our objective was to identify possible effects of non-protected sunflower oil on the milk 
production and milk fatty acid composition in the locally reared Simmental cows and to asses the oxidative status of cows at the same time by measurement of the cellular enzyme that protects cytoplasmic structures against the oxidative stress and by determining an index of lipid peroxidation.

\section{Material and methods}

Ten healthy, multiparous Simmental cows in mid-lactation (78 \pm 40 days in milk [DIM]) were assigned for feeding trial with one of the diet applied: the control (basal) diet (WSO) that contained $26 \%$ corn silage, $33 \%$ perennial ryegrass haylage, and $41 \%$ concentrate in DM, and the experimental diet (SO) where basal diet was supplemented with $200 \mathrm{~g}$ of non-protected sunflower oil per cow daily. The unrefined sunflower oil was purchased form the Edible Oil Factory, Čepin, Croatia. The ingredients and chemical composition of the diet and fatty acid composition of sunflower oil are presented in Table 1 and Table 2. The concentrate mixture was prepared on the daily basis and in the SO diet the sunflower oil was thoroughly mixed with the concentrate mixture. Water was provided for ad libitum consumption. Before the trial had started all cows were fed the same basal diet. After one month period, cows were randomly selected and divided in 2 groups (group 1 and group 2), 5 cows each, and were fed one of the diets for 21 day after change over was applied. Fourteen days wash out period between two treatments was applied. The cows were kept indoors and milked and fed twice daily $(7$ a.m. and 7 p.m.). The milk samples in all cows for the milk components determination and the fatty acid composition were taken once in pre-trial period, and 14th and 21st day after the introduction of sunflower oil in each animal group, altogether in 5 sampling periods. The milk composite of the morning milk was taken from each cow and placed to $20 \mathrm{ml}$ plastic container, and transported at $4^{\circ} \mathrm{C}$ for the milk component analyses in the central laboratory of »Dukat" Dairy Company laboratory where the protein, fat, solids-non fat (SNF), lactose and somatic cell count (SCC) were determined by infrared procedure (MilcoScan 4000; Fossomatic 5000, Denmark). For the fatty acid determination the composite of the regular evening and morning milking of each cow was stored at $-20^{\circ} \mathrm{C}$ until analysed for the fatty acid composition by GC procedure (GC chromatograph SRI 8619C, Quadrex Corporation, New Haven). Lipid extraction was carried out and the preparation of fatty acid methyl esters (FAME) was done according the ISO 14156-IDF 172:2001 and ISO 15884-IDF 182:2002. Aliquots of FAME in chloroform $(1 \mu \mathrm{L})$ were fractionated with a fused silica capillary column (Carbowax $0212051 ; 30 \mathrm{~m} \times 0.25 \mathrm{~mm}$ i.d. $\times 0.25 \mu \mathrm{m}$ filter thickness) using $\mathrm{H}_{2}$ as a carrier gas with a flow of $60 \mathrm{~mL} / \mathrm{min}$. The injector and detector temperatures were $160^{\circ} \mathrm{C}$ and $230^{\circ} \mathrm{C}$, respectively. The initial oven temperature was held at $100^{\circ} \mathrm{C}$ for $10 \mathrm{~min}$, then increased to $160^{\circ} \mathrm{C}$ at $10^{\circ} \mathrm{C}$ per min and held for $7 \mathrm{~min}$, and finally increased to $220^{\circ} \mathrm{C}$ at $5^{\circ} \mathrm{C}$ per min and held for $15 \mathrm{~min}$. All fatty acids determined in this trial were identified by comparing the retention times with methylated standards (Sigma Aldrich Chemie, GmbH and Supelco, USA) and CLA standards were purchased from Matreya INC., $P A$, USA. The quantification of FAME was done using nonadecanoic acid as an internal standard. 
Table 1

Ingredients and chemical composition of the control (WSO) and experimental (SO) diet Futterzusammensetzung der Versuchs- und Kontrollgruppe

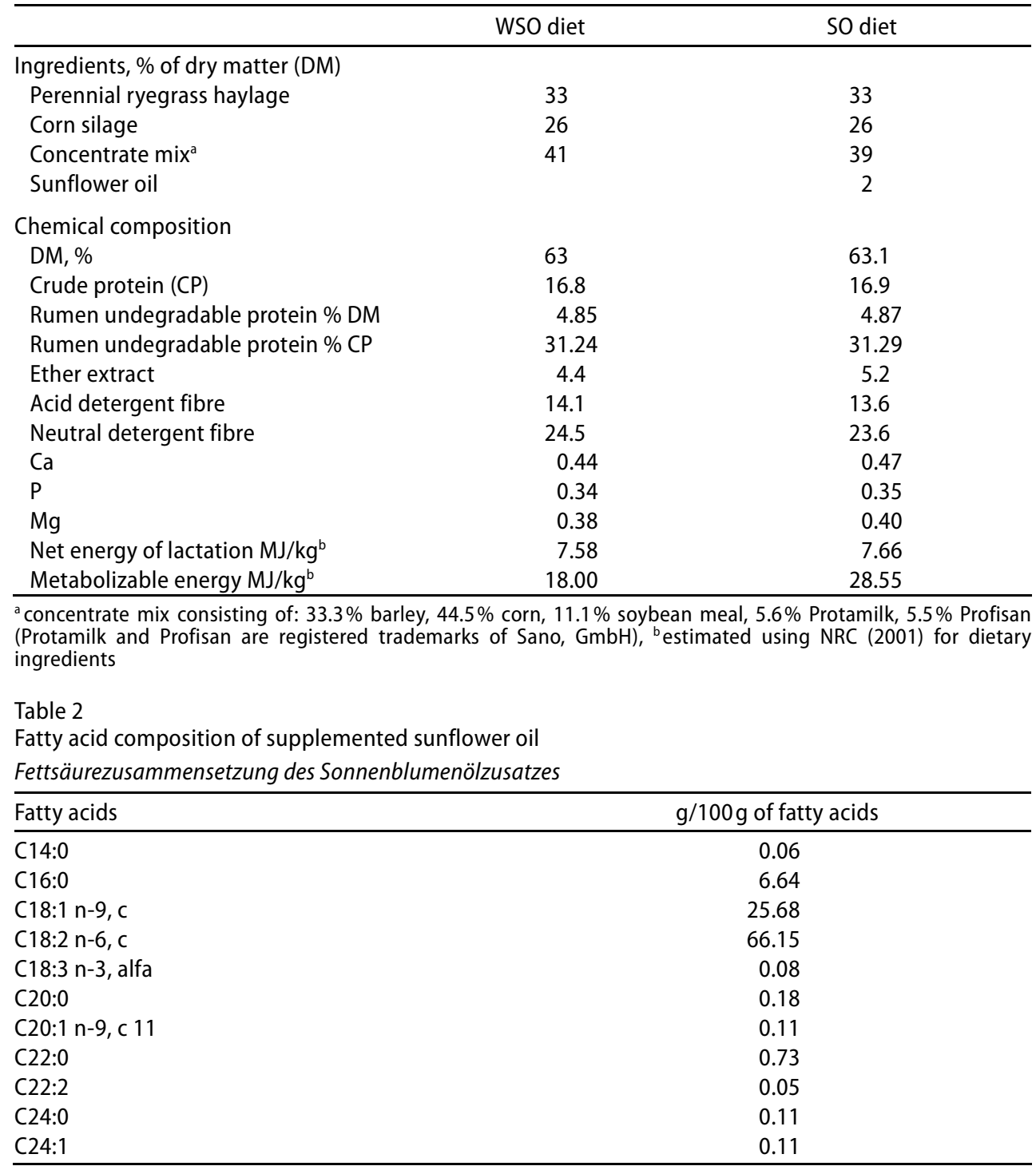

The activity of glutathion peroxidase (GPx) and thiobarbituric acid reactive substances (TBARS) was determined in whole blood. The individual blood samples were collected at the same day of milk collection, 3-4 $\mathrm{h}$ after feeding from the v. jugularis in BD vacutainer tubes (BD Vacutainer System, Plymouth, UK) with lithium heparin (LH 85 I.U.) as the anticoagulant agent. Samples were transported at $4^{\circ} \mathrm{C}$ to the laboratory and whole blood was stored at $-20^{\circ} \mathrm{C}$ until analysed. The GPx activity was measured by a modification of the method of PAGLIA and VALENTINE (1967) using commercial kits (RANSEL, RS 506 »Randox", Ireland) and expressed in U/g of proteins. Enzyme activities were measured in 
a SABA 18 (AMS Italy) at $37^{\circ} \mathrm{C}$. The protein concentration was determined by the LOWRY et al. method (1951). The TBARS concentration was determined with the TROTTA et al. method (1982) in a Helious Thermospectronic, Helios delta spectrophotometer (Unicam, Cambridge, UK) at $25^{\circ} \mathrm{C}$. Absorption peak was measured at $532 \mathrm{~nm}$ and concentration was calculated using molar extinction coefficient of $1.5 \times 10^{5}$.

The data were analysed using the PROC MIXED procedure of SAS (version 8, 1999, SAS Institute Inc. SAS/STAT), with cow, treatment, period, and order as class variables. The statistical model used included treatment, period, and treatment by order interaction. The significance of the difference between the means was evaluated by the Tukey-Kramer test. For all data, significance was declared at $P<0.05$.

\section{Results and discussion}

The results of milk production and standard milk composition are presented in Table 3. We have presumed that quantity of sunflower oil used in the research did not compromise the metabolic pathway of rumen microbes. The fat content in SO diet increased only for $0.8 \%$ and did not exceed possible detrimental level for the normal run of the rumen metabolic processes (Table 1). The routinely analysed milk components were not significant altered (Table 3). On the other hand, we had determined the changes in milk fatty acid profile. In the past decade the growing interest appeared in the area of functional food production. The modification of the fatty acids composition of raw animal products to improve the healthy and nutritional values of food is just one part from that research field. Mostly, all nutritional guidance have prescribed a recommended daily intake of saturated to unsaturated fatty acids, and n-3:n-6 ratio in meal, respectively (SINGH et al. 2004). The benefit of CLA, but also some other long chain fatty acids found in milk, such as $a$ - and $\gamma$-linolenic acid, oleic acid, and eicosapentaenoic (EPA) and docosahexaenoic acid (DHA) has been comprehensively studied (WHIGHAM et al. 2000, PFEUFFER 2001, BADINGA and GREEN 2006). The milk quality, especially at the small-scale dairy farms that are participating at the bigger proportion in Croatia could add a new value regarding the milk quality by improvement of fatty acid composition through modulation of the diet introduced in the farm. The are several approaches to achieve higher proportion of PUFA in milk of dairy cows that are very well presented in CHILLIARD et al. study (2001). Among others the non-protected vegetable oils are used in ruminants' diet, but rarely because of its potential negative effect on rumen microbes. However, FIEVEZ et al. (2003) did not find any adverse effect of oil infusion on the rumen processes. During our research we had been applying the unrefined non-protected sunflower oil as a fat supplement in the daily ration. Regarding the results of our research, the SO treatment resulted in partial modification of fatty acid composition (Table 4). The cis-9, trans-11 C18:2 (CLA) and linoleic acid increased significantly for 0.45 and $0.81 \%$, and palmitic acid decreased for $4.85 \%$, respectively (Table 4 ).

The main C18:2 isomer produced in vitro with linoleic acid supplementation, according to KOLVER et al. study (2002), is cis-9, trans-11 CLA. We could also presume that linoleic acid provided by the non-protected sunflower oil supplementation in the diet, partially bypassed the complete rumen biohydrogenation and served as a precursor for the mammary 
Table 3

The least square mean, standard error of mean (SEM) and minimum significance $(P<0.05)$ of the milk production and milk composition in Simmental cows respective to treatment

Tagesmilchleistung und Milchinhaltstoffe der Vergleichgruppen Simmentaler Kühe

\begin{tabular}{lcccc}
\hline & SO, $n=20$ & WSO, $n=30$ & SEM & $P$ \\
\hline Milk production, L/d & 19.67 & 17.96 & 1.354 & 0.295 \\
Fat, \% & 4.17 & 4.39 & 0.151 & 0.242 \\
Protein, \% & 3.70 & 3.72 & 0.078 & 0.824 \\
Urea, $\mathrm{mmol} / \mathrm{L}$ & 4.84 & 4.61 & 0.363 & 0.574 \\
Lactose, \% & 4.75 & 4.63 & 0.038 & 0.060 \\
Solids non fat, \% & 9.11 & 9.10 & 0.085 & 0.932 \\
Somatic cell count, $\times 1000$ & 44.17 & 38.41 & 12.72 & 0.681 \\
\hline
\end{tabular}

Table 4

The least square mean, standard error of mean $(S E M)$ and minimum significance $(P<0.05)$ and of fatty acids profile of Simmental cows milk respective to treatment

Fettsäureprofil der Milch beider Gruppen

\begin{tabular}{|c|c|c|c|c|c|}
\hline Treatment & & SO, $n=20$ & WSO, $n=30$ & SEM & $P$ \\
\hline Fatty & $\begin{array}{l}\text { acids } \\
\text { Trivial/systematic name }\end{array}$ & & $\mathrm{g} / 100 \mathrm{~g}$ of & ty acids & \\
\hline C8:0 & Caprylic & 2.56 & 2.48 & 0.144 & 0.72 \\
\hline C10:0 & Capric & 2.31 & 2.69 & 0.218 & 0.17 \\
\hline C10:1 & Decenoic & 0.32 & 0.26 & 0.074 & 0.48 \\
\hline C11:0 & Undecanoic & 0.16 & 0.06 & 0.057 & 0.18 \\
\hline $\mathrm{C} 12: 0$ & Lauric & 3.54 & 4.17 & 0.222 & 0.07 \\
\hline C12:1 & Dodecenoic & 0.22 & 0.23 & 0.097 & 0.94 \\
\hline $\mathrm{C} 13: 0$ & Tridecanoic & 0.19 & 0.32 & 0.102 & 0.29 \\
\hline C $14: 0$ & Miristic & 11.09 & 12.28 & 0.529 & 0.11 \\
\hline C14:1 & Miristoleic & 1.44 & 1.45 & 0.104 & 0.76 \\
\hline C15:0 & Pentadecilic & 1.14 & 1.19 & 0.146 & 0.78 \\
\hline C15:1 & Pentadecenoic & 0.49 & 0.50 & 0.083 & 0.85 \\
\hline $\mathrm{C} 16: 0$ & Palmitic & 25.14 & 29.99 & 1.427 & 0.04 \\
\hline C16:1 & Palmitoleic & 2.74 & 3.00 & 0.065 & 0.89 \\
\hline $\mathrm{C} 17: 0$ & Margaric & 0.46 & 0.48 & 0.076 & 0.77 \\
\hline C $17: 1$ & Heptadecenoic & 0.41 & 0.35 & 0.123 & 0.65 \\
\hline C18:0 & Stearic & 15.77 & 11.49 & 1.454 & 0.06 \\
\hline C18:1 cis-9 & Oleic & 21.93 & 21.38 & 1.165 & 0.67 \\
\hline C18:1 trans-11 & Vaccenic & 1.19 & 0.53 & 0.280 & 0.10 \\
\hline C18:2 cis-9, cis-12 & Linoleic & 3.56 & 2.75 & 0.240 & 0.04 \\
\hline C18:2 cis-9, trans- 11 & Conjugated linoleic & 1.25 & 0.80 & 0.130 & 0.04 \\
\hline C18:3 cis-9, cis-12, cis-15 & a-linoleic & 0.58 & 0.47 & 0.172 & 0.56 \\
\hline C18:3 cis-6, cis-9, cis-12 & $\mathrm{y}$-linolenic & 0.21 & 0.12 & 0.095 & 0.52 \\
\hline$C 20: 0$ & Arachidic & 0.21 & 0.14 & 0.072 & 0.36 \\
\hline C20:1 & Gondoic & 0.24 & 0.12 & 0.114 & 0.42 \\
\hline$C 20: 4$ & Arachidonic & 0.19 & 0.15 & 0.063 & 0.62 \\
\hline $\mathrm{C} 20: 5$ & Timnodonic & 0.36 & 0.32 & 0.106 & 0.75 \\
\hline$C 22: 0$ & Behenic & 0.20 & 0.26 & 0.067 & 0.49 \\
\hline C22:1 & Erucic & 0.25 & 0.27 & 0.074 & 0.81 \\
\hline$C 22: 6$ & Cervonic & 0.20 & 0.15 & 0.087 & 0.59 \\
\hline C24:0 & Nervonic & 0.12 & 0.10 & 0.045 & 0.61 \\
\hline
\end{tabular}


CLA synthesis, and was incorporated to milk fat. As opposed to BETT et al. (2004) and REGO et al. (2005b) studies in present research the supplementation of sunflower oil did not significantly changed the stearic and oleic acid content in milk (Table 4). The oleic acid has an important role in oil and fat emulsification in ruminants (NRC 2001), and therefore, with a higher inflow of long chain fatty acid in the small intestine, more oleic acid might have been utilised and even needed. VAN DE VOSSENBERG and JOBLIN (2003) also documented the lower desaturation rate of stearic to oleic acid in sufficient presence of some other unsaturated fatty acids, in our case linoleic acid, for the purpose of mammary gland fat synthesis. Therefore, in present research no possible increase in milk oleic acid was noticed. Moreover, no significant increase of trans-vaccenic acid (TVA; trans-11 (18:0) was remarked, even it is well known that TVA is a second intermediate of linoleic acid biohydrogenation process in the rumen. It may be presumed that the majority of TVA was endogenously converted to CLA in the mammary tissue and therefore no significant increase of TVA in milk was registered. The significantly lower palmitic acid content, conditioned by the sunflower oil treatment, and the somewhat lower proportion of myristic acid in milk, probably demonstrate an alteration of de novo mammary gland fatty acids synthesis. Similarly, in YEOM et al. (2005) and WALISIEWICZNIEDBALSKA et al. (2004) research the incorporation of linoleic acid in the diet of goat kids increased the carcass linoleic acid content and simultaneously reduced the proportion of medium chain fatty acids. It could be presumed that linoleic acid lowered the enzyme activity for the synthesis of milk fatty acids with less than 16 carbon atoms which is suggested in the LOOR and HERBEIN (1998) and PIPEROVA et al. studies (2000).

The $\Delta^{9}$-desaturase activity was indirectly measured by comparing the product:substrate rations of certain fatty acids (Figure 1). The increase in proportion of miristoleic acid (C14:1), that is considered to be the best indirect indicator of $\Delta^{9}$-desaturase activity in mammary gland, revealed enhanced desaturation of miristic acid (C14:0) and higher $\Delta^{9}$-desaturase activity in the mammary gland during the $\mathrm{SO}$ treatment. Contrary, decreased CLA:TVA ratio means lower $\Delta^{9}$-desaturase activity (Figure 1 ) that seems contradictory with appearance of significantly higher CLA content in milk (Table 4).

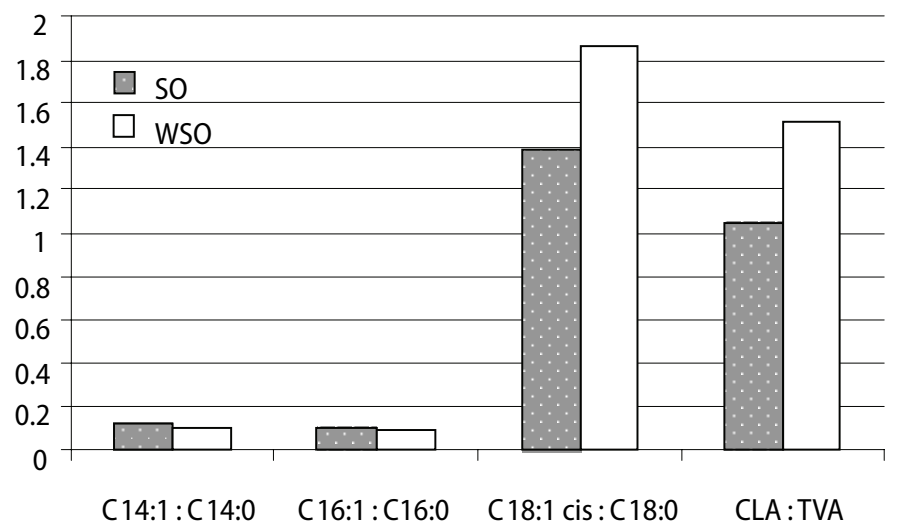

Figure 1

Indirect measurement of $\Delta^{9}$-desaturase activity by comparing the product:substrate ratio in WSO and SO Indirekte Messung der $\Delta^{9}$-Desaturaseaktivität beider Vergleichsgruppen 
The CLA may have been partly absorbed from the blood and seemed to exceed the endogenous synthesis in present study. The linoleic acid that was mostly presented in the sunflower oil (Table 2) could be toxic for the rumen bacteria, but also might be a stimulus for the bacterial growth, according to KOPPOVA et al. (2006) research.

Some concerns regarding the possible negative effect of oil in the diet on the milk fat synthesis and »low milk fat" phenomena as well as eventual animal health implications appeared before the experiment started. It is known that unsaturated fatty acids are very potent biological agents extensively prone to lipid peroxidation that may initiate degenerative changes and disease. The mobilisation of the fatty acid from the fat depot during the low energy intake in dairy cows could be identified with the higher inflow of fats during the fat supplementation in the diet (CHILLIARD et al. 2000) that could increase liver fat content and cause the lipid peroxidation of the liver tissue, especially if the antioxidants supply, and antioxidant potential is not adequate. Therefore, the one of the scope of the present research was also focused on the measurement of oxidative defence ability by determining the cellular enzyme activity and to identify degree of lipid peroxidation. The linoleic acid from the supplemented sunflower oil might have amplified the formation of lipid peroxide and possibly induced the oxidative stress.

According to BLACHE et al. (2006) the well-balanced diet produces fewer free radicals and therefore less cell damage. However, BROWN et al. (2003) claimed no oxidative damage caused by oxidative stress alone. In the present study, the rise of GPx activity in blood for $25.14 \mathrm{U} / \mathrm{g}$ of proteins and adversely significantly lower TBARS concentration (Table 5) during the SO treatment may indicate sufficient antioxidant defence ability of treated cows, and even lower production of secondary lipid products during the SO treatment may be a result of some antioxidant agents directly provided by the unrefined sunflower oil. On the other hand, JOO et al. (2002) reported lower TBARS concentration in the loins of pigs fed with CLA that might suggest antioxidant role of CLA in prevention of peroxide formation (HA et al. 1990, VACLAVKOVA and BECKOVA 2007). The CLA content in milk positively correlates with the concentration of CLA in blood plasma, according to CORL et al. experiment (2003). Therefore, we may suspect the possible role of CLA as antioxidant agent in the present study.

Table 5

The least square mean and standard deviation (SD) of GPx and TBARS in blood of Simmental cows respective to treatment

GPx und TBARS im Blut der Vergleichsgruppen

\begin{tabular}{lcc}
\hline Treatment & SO, $n=20$ & WSO, $n=30$ \\
\hline GPx (U/g prot.) & $112.98 \pm 19.80^{*}$ & $87.84 \pm 26.71$ \\
TBARS (nmol/L) & $10.19 \pm 3.85^{*}$ & $13.45 \pm 1.65$ \\
\hline
\end{tabular}

${ }^{*} P<0.05$

On the other hand, the antioxidants may act as pro-oxidants in human and animal cells in the condition of sustained and overdose (RISÉRUS et al. 2002). The antioxidant requirements, even in humans are still difficult to assess, and in dairy cows they are depended on various factors, such as concentration of antioxidants in feedstuffs and in the soil, climate conditions and hormonal status. 
The results of the present research showed that non-protected sunflower oil in the diet of Simmental cows partially modified the fatty acid composition of milk, especially in the area of C18:2 and of C16:0 fatty acids. The bioactive fatty acids, cis-9, trans-11 CLA increased significantly in the milk fat, and at the same time the milk fat content remained stable during the study. An increase in blood GPx activity during the sunflower oil treatment may presume an effective role of GPx in quenching the free radicals eventually produced by the peroxidation of unsaturated fatty acids derived from the unrefined sunflower oil that might have provided the certain amount of other antioxidant elements that additionally increased the antioxidant defence ability. The effect of the higher dosage and prolonged use of non-protected fats on the milk composition and animals and human health should be further studied.

\section{Acknowledgements}

The research was supported by grant of Ministry of Science, Education and Sports of the Republic of Croatia (Grant No.053-0531854-1850).

\section{References}

Badinga L, Greene ES (2006) Physiological Properties of Conjugated Linoleic Acid and Implications for Human Health. Nutr Clin Pract 21, 367-73

Bett V, Dal Secco de Oliveira M, Matsushits M, Arlington Headley S, Evelazio de Souza N (2004) Effect of sunflower oilseed supplementation on fatty acid profile and milk composition from Holstein cows. Acta Sci 26, 95-101

Blache D, Devaux S, Joubert O, Loreau N, Schneider M, Durand P, Prost M, Gaume V, Adrian M, Laurant P, Berthelot A (2006) Long-term moderate magnesium-deficient diet shows relationships between blood pressure, inflammation and oxidant stress defence in aging rats. Free Radical Bio Med 4,1277-84

Brown KE, Dennery PA, Ridnour LA, Fimmel CJ, Kladney RD, Brunt EM, Spitz DR (2003) Effect of iron overload and dietary fat on indices of oxidative stress and hepatic fibrinogenesis in rats. Liver Int 23, 232-42

Chilliard Y, Ferlay A, Doreau M (2001)Effect of different types of forages, animal fat or marine oils in cows' diet on milk fat secretion and composition, especially conjugated linoleic acid (CLA) and polyunsaturated fatty acids. Livest Prod Sci 70, 31-48

Corl BA, Barbano DM, Bauman DE, IP C (2003) cis-9, trans-11 CLA derived endogenously from trans-11 18:1 reduces cancer risk in rats. J Nutr 133, 2893-900

Dannenberger D, Nuernberg K, Nuernberg G, Ender K (2006) Carcass and meat quality of pasture concentrat feed German Simmental and German Holstein bulls. Arch Tierz 49, 315-28

DePeters E, Medrano RF, Reed BA (1995) Fatty-acid composition of milk-fat from 3 breeds of dairy cattle. Canadian. J Anim Sci 75, 267-9

Dhiman TR, Anand GR, Satter LD, Pariza MW (1999) Conjugated linoleic acid content of milk from cows fed different diets. J Dairy Sci 82, 2146-56

Fievez V, Dohme F, Daneels M, Raes K, Demeyer D (2003) Fish oils as potent rumen metahen inhibitors and associated effects on rumen fermentation in vitro and in vivo. Anim Feed Sci Tech 104, 41-58

Geissler B, Trilk J, Fickel A (1994) Rumen protected feed in diary cow feeding. Arch Tierz 37, 401-9 [in German]

$\mathrm{Ha}$ Yl, Storkoson J, Pariza MW (1990) Inhibition of benzo(a)pyrene-induced mouse forestomach neoplasia by conjugated dienoic derivatives of linoleic acid. Cancer Res 50, 1097-101

Harfoot CG, Hazlewood GP (1997) Lipid metabolism in the rumen. In: Hobson PN, Stewart CS (eds) The Rumen Microbial Ecosystem, Chapman and Hall, New York, USA, 382-426

Holló G, Nuernberg K, Repa I, Holló I, Seregi J, Pohn G, Ender K (2005) Effect of feeding on the composition of the intramuscular fat in longissimus muscle and different fatty tissues of Hungarian Grey and Holstein Friesian bulls. 1. Fatty acid profile. Arch Tierz 48, 537-46 [in German]

Joo ST, Lee Jl, Ha YL, Park GB (2002) Effects of dietary conjugated linoleic acid on fatty acid composition, lipid oxidation, colour, and water-holding capacity of pork loin. J Anim Sci 801,108-12 
Kolver ES, DE Veth MJ, Roche JR, Chand A (2002) Enhancing ruminal concentrations of conjugated linoleic acid and trans vaccenic acid. J Dairy Sci 85 Suppl 1, 730

Koppova I, Lukash F, Kopečny J (2006) Effect of fatty acids on growth of conjugated linoleic acid producing bacteria in rumen. Folia microbial 51, 291-3

Leibetseder J (1996) Influence on the composition of animal fat by nutrition. Arch Tierz 39, 333-45 [in German]

Loor JJ, Herbein JH (1998) Exogenous conjugated linoleic acid isomers reduce bovine milk fat concentration and yield by inhibiting de novo synthesis. J Nutr 128, 2411-9

Marenjak TS, Poljičak-Milas N (2007) Seasonal variations in raw milk quality and milk production on small-holder dairy farms in Croatia. Milchwiss 62, 273-5

NRC (2001) Nutrient requirements of dairy cattle. National Academic Press, 7th revised ed Washington DC, USA

Paglia DE, Valentine WN (1967) Studies on the quantitative and qualitative characterization of erythrocyte glutathione peroxidase. J Lab Clin Med 70, 158-69

Pfeuffer M (2001) Physiologic effects of individual fatty acids in animal and human body, with particular attention to coronary heart disease risk modulation. Arch Tierz 44, 89-98

Piperova LS, Teter BB, Bruckental I., Sampagna J, Mills SE, Yurawecz MP, Fritsche J, Ku K, Erdman RA (2000) Mammary lipogenic enzyme activity, trans fatty acids conjugated linoleic acid isomers during milk fat depression in lactating dairy cows. J Nutr 130, 2568-74

Precht D, Molkentin J (1997) Effect of feeding on conjugated cis-9, trans-11 octadecadienoic acid and other isomers of linoleic acid in bovine milk fats. Nahrung 41, 330-35

Rego A, Rosa HJD, Portugal PV, Franco T, Vouzela CM, Borba AES, Bessa RJB (2005) The effects of supplementation with sunflower and soybean oil on the fatty acid profile of milk in grazing dairy cows. Anim Res 54,17-24

Risérus U, Basu S, Jovinge S, Fredrikson GN, Ärnlöv J, Vessby B (2002) Supplementation with conjugated linoleic acid causes isomer-dependent oxidative stress and elevated c-reactive protein. Circulation 106, 1925-9

Secchiari P, Antongiovanni M, Mele M, Serra A, Buccioni A, Ferruzzi G, Paoletti F, Petacchi F (2003) Effect of kind of dietary fat on the quality of milk fat from Italian Friesian cows. Livest Prod Sci 83, 43-52

Singh K, Hartley DG, Mcfadden TB, Mackenzie DDS (2004) Dietary fat regulates mammary stearoyl CoA desaturase expression and activity in lactating mice. J Dairy Res 71, 1-6

Szumacer-Strabel M, Potkanski A, Cieslak AQ (2001) Effect of protected fat on fatty acid composition and conjugated linoleic acid level in meat and milk of sheep Arch Tierz $44 \mathrm{SI}, 329-35$

Stanton C, Lawless F, Kjellmer G, Harrington D, Devery R, Connolly JF, Murphy J (1997) Dietary influences on bovine milk cis-9, trans-11-conjugated linoleic acid content. J Food Sci 62, 1083-6

Trotta RJ, Sullivan SG, Stern A (1982) Lipid Peroxidation And Hemoglobin Degeneration In Red Blood Cells Exposed To T-Butyl Hydroperoxide. Biochem J 204, 405-15

Van Asselt M, Van Dijk S, Kuiper R (2006) Fat necrosis as a herd problem in heifers with low GSH-Px levels. In: OS31-2, 1/1 CD, 24th World Buiatrics Congress, 15-19. October, Nice, France

Van de Vossenberg JLCM, Joblin K (2003) Biohydrogenation of C18 unsaturated fatty acids to stearic acid by a strain of Butyvibrio hungatei from the bovine rumen. Lett Appl Microbiol 37, 424

Vaclavkova E, Beckova R (2007) Effect of linseedin pig diet on meat qualityand fatty acid content. Arch Tierz 50 SI, 144-51

Walisiewicz-Niebalska W, Patkowska-Sokola B, Bodkowski R, Rozycki K (2004) The influence of linoleic acid and its isomers in goat diet on the oomposition of fatty acid in goat milk fat. Arch Tierz $47 \mathrm{SI}, 103-107$

Whigham ID, Cook ME, Atkinson RL (2000) Conjugated linoleic acid: implication for human health. Pharm Res 42, 503-10

Yeom KH, Schonewille JH, Everts HK, Lee W, Van Trierum G, Beynen A (2005) Growth performance and body composition of goat kids fed milk replacers with increasing levels of linoleic acid. J Anim Physiol A N 89, 29-34

Received 4 December 2007, accepted 9 June 2009.

Corresponding author:

TEREZIJA SILVIJA MARENJAK, PhD DVM

email: marenjak@vef.hr

Department of Pathophysiology, Faculty of Veterinary Medicine, University of Zagreb, Henzelova 55,

10000 Zagreb, Croatia 